\title{
PENGARUH SUDUT KERJA PENGELASAN TERHADAP KEKUATAN LAS PADA LINK ENGINE HANGER TIPE K16
}

\author{
Jamaludin \\ Dosen Teknik Mesin Universitas Muhammadiyah Tangerang \\ Email :jamaludinpermana14@yahoo.com
}

\begin{abstract}
ABSTRAK
Pengelasan adalah suatu proses penggabungan logam dimana logam menjadi satu akibat panas las,dengan atau tanpa pengaruh tekanan dan dengan atau tanpa logam pengisi,kerja las adalah menyambung dua bagian logam atau lebih dengan menggunakan energi panas, Proses pengelasan berkaitan dengan lempengan baja yang dibuat dari kristal besi dan karbon sesuai struktur mikronya, dengan bentuk dan arah tertentu. Lalu sebagian dari lempengan logam tersebut dipanaskan hingga meleleh.Kalau tepi lempengan logam itu disatukan, terbentuklah sambungan. Umumnya, pada proses pengelasan juga ditambahkan dengan bahan penyambung seperti kawat atau batang las. Kalau campuran tersebut sudah dingin, molekul kawat las yang semula merupakan bagian lain kini menyatu.Besarnya arus pengelasan yang diperlukan tergantung pada diameter elektroda, tebal bahan yang dilas, jenis elektroda yang digunakan, geometri sambungan, diameter inti elektroda, posisi pengelasan. Daerah las mempunyai kapasitas panas tinggi maka diperlukan arus yang tinggi.Pada standard welding inspection material tipis di lambangkan dengan $\mathrm{t} 1$, dan material tebal di lambangkan dengan $\mathrm{t} 2$. Dalam proses pengelasan material pengisi harus memakan sebagian dari tebal material asli 1 dan tebal material asli 2.menunjukkan bahwa titik 1 sampai dengan 3 adalah nilai kekerasan untuk daerah las, nilai rata - ratanya adalah $25.88 \frac{\mathrm{kg}}{\mathrm{mm}^{2}}$. Titik ke 4 yang terdapat pada grafik menunjukkan nilai kekerasan dari batas daerah lasan dengan daerah HAZ dengan nilai kekerasannya adalah $24.78 \frac{\mathrm{kg}}{\mathrm{mm}^{2}}$. Titik ke 5 sampai 8 merupakan daerah HAZ yang memiliki nilai rata - rata kekerasan sebesar $38.40 \frac{\mathrm{kg}}{\mathrm{mm}^{2}}$. Titik 9 merupakan batas antara daerah HAZ dengan daerah logam induk yang memiliki nilai kekerasan sebesar $32.96 \frac{\mathrm{kg}}{\mathrm{mm}^{2}}$. Titik 10 sampai 12 merupakan daerah logam induk yang memiliki nilai rata - rata kekerasan sebesar $32.97 \frac{\mathrm{kg}}{\mathrm{mm}^{2}}$. Dari data tabel dan grafik diatas nilai kekerasan tertinggi spesimen dengan variasi sudut pengelasan $30^{\circ}$ berada pada daerah $\mathrm{HAZ}$ yaitu sebesar $38.94 \frac{\mathrm{kg}}{\mathrm{mm}^{2}}$.
\end{abstract}

Kata Kuci :kekerasan, welding, elektroda, HAZ

\section{PENDAHULUAN}

Dengan semakin majunya teknologi sekarang ini teknik penyambungan pengelasan ( welding ) angatlah penting. Pengelasan menurut Kamus besar Bahasa Indonesia (1994), " adalah penyambungan besi dengan cara membakar. Dalam referensi-referensi teknis, terdapat beberapa definisi dari Las, yakni sebagai berikut:Berdasarkan defenisi dari Deutsche Industrie Normen (DIN) dalam Harsono dkk(1991:1), mendefinisikan bahwa " las adalah ikatan metalurgi pada sambungan logam paduan yang dilakukan dalam keadaan lumer atau cair ". Sedangkan menurut maman suratman (2001:1) mengatakan tentang pengertian mengelas yaitu salah satu cara menyambung dua bagian logam secara permanen dengan menggunakan tenaga panas. menurut Sriwidartho, Las adalah suatu cara untuk menyambung benda padat dengan dengan jalan mencairkannya melalui pemanasan. Menurut "Welding handbook" pengelasan adalah proses penyambungan bahan yang menghasilkan peleburan bahan dengan memanasinya dengan suhu yang tepat dengan atau tanpa pemakaian bahan pengsisi. Pengelasan adalah suatu proses penggabungan logam dimana logam menjadi satu akibat panas las,dengan atau tanpa pengaruh tekanan dan dengan atau tanpa logam pengisi (Howards, 1981).Dari beberapa pendapat di atas, maka dapat disimpulkan bahwa kerja las adalah menyambung dua bagian logam atau lebih dengan menggunkan energi panasProses pengelasan berkaitan dengan lempengan baja yang dibuat dari kristal besi dan karbon sesuai struktur mikronya, dengan bentuk dan arah tertentu. Lalu sebagian dari lempengan logam tersebut dipanaskan hingga meleleh.Kalau tepi lempengan logam itu disatukan, terbentuklah sambungan. Umumnya, 
pada proses pengelasan juga ditambahkan dengan bahan penyambung seperti kawat atau batang las. Kalau campuran tersebut sudah dingin, molekul kawat las yang semula merupakan bagian lain kini menyatu.Banyak hal - hal yang harus di perhatikan dalam proses pengelasan di antaranya adalah menentukan parameter pengelasan. pemilihan parameter welding akan menentukan bagaimana hasil weldingan. Jika pemilihan parameter nya tepat maka hasil welding nya pun akan bagus, Mulai dari visual nya maupun dari segi struktur mikro nya.

\section{TUJUAN PENELITIAN}

Adapun tujuan dari penelitian ini adalah:

1. Mengetahui hasil uji mikro pengelasan serta kekuatan dari hasil pengelasan dengan berbagai variasi sudut kerja pengelasan .

2. Untuk mengetahui cara menentukan sudut kerja pengelasan dan berbagai posisi dari pengelasan dengan tepat.

\section{BATASAN MASALAH}

Melihat begitu kompleksnya permasalah mengenai pengelasan, maka dalam penelitian ini penulis membatasi masalah Peneliti mempelajari pengaruh sudut kerja pengelasan pada proses welding link engine hanger terhadap hasil uji mikro pengelasan dengan material STKM 11A,Standarisasi hasil Proses welding yang baik merujuk pada welding inspection standard dan AWS D1.1.

1. Cara pengujian mikro link engine hanger type $k 16$

2. Sudut ideal untuk pengelasan link engine hanger type $k 16$

Dalam penginputan pengujian - pengujian lain pada hasil welding, pada saat Peneliti melaksanakan Penelitian di bagian welding robotic dan pengujian pengelasan

\section{MANFAAT PENELITIAN}

1. Bagi Penulis Merupakan sarana dalam menerapkan ilmu yang didapatkan di bangku kuliah

2. Bagi Akademik dapat memberikan tambahan referensi untuk pengembangan berikutnya

3. Bagi Industri dapat memberikan tambahan pengetahuan atau informasi bagi pihak industri dalam mendesain dan merencanakan suatu desain konstruksi khususnya bermaterial pelat baja

\section{LANDASAN TEORI}

\section{Sejarah Las (welding)}

Pengelasan dengan metode yang dikenal sekarang, mulai dikenal pada awal abad ke 20. Sebagai sumber panas digunakan api yang berasal dari pembakaran gas acetylena yang kemudian dikenal sebagai las karbit. Waktu itu sudah dikembangkan las listrik namun masih mulai langka.

Pada Perang Dunia II, proses pengelasan untuk pertama kalinya dilakukan dalam skala besar. Dengan las listrik, dalam waktu singkat, Amerika Serikat dapat membuat sejumlah kapal sekelas dengan kapalSS Liberty, yang merupakan kapal pertama yang diluncurkan dengan di Las. Di mana sebelumnya kapal yang dikeluarkan, proses pengerjaan menggunakan paku keling("rivets").

\section{Definisi Las (welding)}

Lingkup penggunaan teknik pengelasan dalam konstruksi sanagat luas, meliputi perkapalan, jembatan, rangka baja, bejana tekan, pipa pesat, pipa saluran, chasis motor dan sebagaianya. Rancangan Las dan cara pengelasan harus betulbetul memperhatikan dan memperlihatkan kesesuaian antara sifat-sifat las dengan kegunaan serta kegunaan disekitarnya.

Prosedur pengelasan kelihatanya sederhana, tetapi sebenarnya didalamnya banyak masalah-masalah yang harus diatasi dimana pemecahanya memerlukan bermacam _ macam pengetahuan.Karena itu di dalam pengelasan, pengetahuan harus turut serta mendampingi praktek, secara lebih terperinci dapat dikatakan bahwa perancangan konstruksi bangunan ataupun kostruksi mesin dengan sambungan las, harus direncanakan pula tentang cara-cara pengelasan. Cara ini pemeriksaan bahan las, jenis las yang akan digunakan, berdasarkan fungsi dari bagianbagian bangunan atau kerangka mesin yang dirancang.

Las menurut Kamus besar Bahasa Indonesia (1994) adalah penyambungan besi dengan cara membakar. Dalam referensi-referensi teknis, terdapat beberapa definisi dari Las, yakni sebagai berikut :

Berdasarkan defenisi dari Deutsche Industrie Normen (DIN) dalam Harsono dkk(1991:1), mendefinisikan bahwa " las adalah ikatan 
metalurgi pada sambungan logam paduan yang dilakukan dalam keadaan lumer atau cair ". Sedangkan menurut Maman suratman (2001:1) mengatakan tentang pengertian mengelas yaitu salah satu cara menyambung dua bagian logam secara permanen dengan menggunakan tenaga panas. Menurut Sriwidartho, Las adalah suatu cara untuk menyambung benda padat dengan dengan jalan mencairkannya melalui pemanasan. Menurut "Welding handbook" pengelasan adalah proses penyambungan bahan yang menghasilkan peleburan bahan dengan memanasinya dengan suhu yang tepat dengan atau tanpa pemakaian bahan pengsisi. Pengelasan adalah suatu proses penggabungan logam dimana logam menjadi satu akibat panas las,dengan atau tanpa pengaruh tekanan dan dengan atau tanpa logam pengisi (Howards, 1981).

Dari beberapa pendapat di atas, maka dapat disimpulkan bahwa kerja las adalah menyambung dua bagian logam atau lebih dengan menggunkan energi panas

Proses pengelasan berkaitan dengan lempengan baja yang dibuat dari kristal besi dan karbon sesuai struktur mikronya, dengan bentuk dan arah tertentu. Lalu sebagian dari lempengan logam tersebut dipanaskan hingga meleleh.Kalau tepi lempengan logam itu disatukan, terbentuklah sambungan. Umumnya, pada proses pengelasan juga ditambahkan dengan bahan penyambung seperti kawat atau batang las. Kalau campuran tersebut sudah dingin, molekul kawat las yang semula merupakan bagian lain kini menyatu.

Didalam proses pengelasan ada banyak faktor yang menentukan hasil pengelasan nya. Biasanya istilah ini dikenal dengan parameter dasar pengelasan.Unutk mengetahui lebih dalam mengenai parameter dasar pengelasan bisa di lihat di halaman selanjutnya.

\section{Metalurgi Las}

Pengelasan adalah suatu proses penyambungan dua bahan logam dengan mempergunakan energi panas, proses ini menyebakan logam disekitar lasan mengalami siklus termal yang sangat cepat dan menyebabkan terjadinya perubahan metalurgi yang cukup rumit, deformasi dan tegangan termal. Perubahan ini sangat berhubungan dengan ketangguhan, cacat, retak, las dan lainnya yang umumnya mempunyai pengaruh langsung terhadap keamanan dan konstruksi las.

\section{Siklus Termal Daerah Las}

Daerah lasan dibagi menjadi 3 bagian yaitu logam lasan, daerah pengaruh las yang dalam bahasa inggris adalah "HEAT AFFECTED ZONE" yang disingkat menjadi daerahh HAZ dan logam induk yang tidak terpengaruhi.

Logam las adalah bagian dari logam yang pada waktu pengelasan mencair kemudian membeku. Daerah HAZ adalah logam dasar yang besebelahan dengan logam las yang selama proses pengelasan mengalami siklus termal pemanasan dan pendinginan yang cepat. Logam induk tak terpengaruhi adalah bagian logam dasar yang tidak menglami perubahan - perubahan struktur dan sifat yang diakibatkan dari panas dan suhu pengelasan.

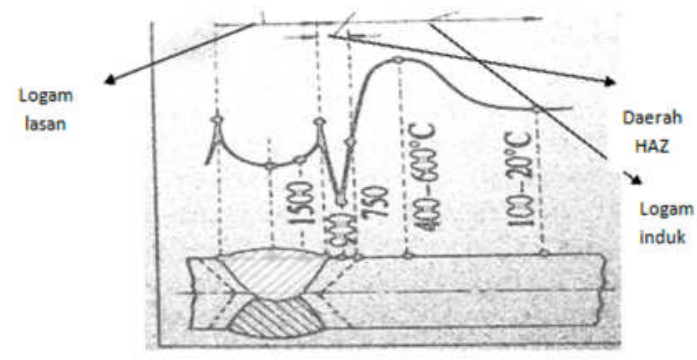

\section{Gambar 2.1 Daerah lasan}

\section{Besar Arus Listrik}

Besarnya arus pengelasan yang diperlukan tergantung pada diameter elektroda, tebal bahan yang dilas, jenis elektroda yang digunakan, geometri sambungan, diameter inti elektroda, posisi pengelasan. Daerah las mempunyai kapasitas panas tinggi maka diperlukan arus yang tinggi.

Arus las merupakan parameter las yang langsung mempengaruhi penembusan dan kecepatan pencairan logam induk. Makin tinggi arus las makin besar penembusan dan kecepatan pencairannya. Besar arus pada pengelasan mempengaruhi hasil las bila arus terlalu rendah maka perpindahan cairan dari ujung elektroda yang digunakan sangat sulit dan busur listrik yang terjadi tidak stabil. Panas yang terjadi tidak cukup untuk melelehkan logam dasar, sehingga menghasilkan bentuk rigi-rigi las yang kecil dan tidak rata serta penembusan kurang dalam. Jika arus terlalu besar, maka akan menghasilkan manik 
melebar, butiran percikan kecil, penetrasi dalam serta peguatan matrik las tinggi.

\section{Struktur Mikro Daerah Las-lasan}

Daerah las-lasan terdiri dari tiga bagian yaitu: daerah logam las, daerah pengaruh panas atau heat affected zone disingkat menjadi HAZ dan logam induk yang tak terpengaruhi panas.

\section{Daerah logam las}

Daerah logam las adalah bagian dari logam yang pada waktu pengelasan mencair dan kemudian membeku. Komposisi logam las terdiri dari komponen logam induk dan bahan tambah dari elektroda. Karena logam las dalam proses pengelasan ini mencair kemudian membeku, maka kemungkinan besar terjadi pemisahan komponen yang menyebabkan terjadinya struktur yang tidak homogen, ketidakhomogennya struktur akan menimbulkan struktur ferit kasar dan bainit atas yang menurunkan ketangguhan logam las. Pada daerah ini struktur mikro yang terjadi adalah struktur cor. Struktur mikro di logam las dicirikan dengan adanya struktur berbutir panjang (columnar grains). Struktur ini berawal dari logam induk dan tumbuh ke arah tengah daerah logam las.

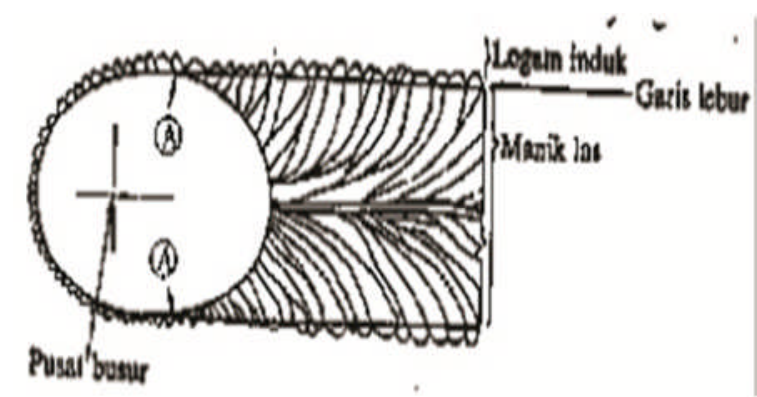

Gambar 2.2 Arah Pembekuan Dari Logam Las

Dari Gambar 2.2 diatas ditunjukkan secara skematik proses pertumbuhan dari kristal-kristal logam las yang pilar. Titik A dari gambar adalah titik mula dari struktur pilar yang terletak dari logam induk. Titik ini tumbuh menjadi garis lebur dengan arah sama dengan sumber panas. Pada garis lebur ini sebagian dari logam dasar ikut mencair selama proses pembekuan logam las tumbuh pada butir-butir logam induk dengan sumbu kristal yang sama.

Penambahan unsur paduan pada logam las menyebabkan struktur mikro cenderung berbentuk bainit dengan sedikit ferit batas butir, kedua macam struktur mikro tersebut juga dapat terbentuk, jika ukuran butir austenitnya besar. Waktu pendinginan yang lama akan meningkatkan ukuran batas butir ferit, selain itu waktu pendinginan yang lama akan menyebabkan terbentuk ferit Widmanstatten. Struktur mikro logam las biasanya kombinasi dari struktur mikro dibawah ini:

1. Batas butir ferit, terbentuk pertama kali pada transformasi austenit-ferit biasanya terbentuk sepanjang batas austenit pada suhu $100^{\circ}$ $650^{\circ} \mathrm{C}$.

2. Ferit Widmanstatten atau ferrite with aligned second phase, strukturmikro ini terbentuk pada suhu 750-6500C di sepanjang batas butir austenit, ukurannya besar dan pertumbuhannya cepat sehingga memenuhi permukaan butirnya.

3. Ferit acicular, berbentuk intragranular dengan ukuran yang kecil dan mempunyai orientasi arah yang acak. Biasanya ferit acicular initerbentuk sekitar suhu $650^{\circ} \mathrm{C}$ dan mempunyai ketangguhan paling tinggi dibandingkan struktur mikro yang lain.

4. Bainit, merupakan ferit yang tumbuh dari batas butir austenit dan terbentuk pada suhu $400-500^{\circ} \mathrm{C}$. Bainit mempunyai kekerasan yang lebih tinggi dibandingkan ferit, tetapi lebih rendah dibanding martensit.

5. Martensit akan terbentuk, jika proses pengelasan dengan pendinginan sangat cepat, struktur ini mempunyai sifat sangat keras dan getas sehingga ketangguhannya rendah.

\section{Daerah Pengaruh Panas Atau Heat Affected} Zone (HAZ)

Daerah pengaruh panas atau heat affected zone (HAZ) adalah logam dasar yang bersebelahan dengan logam las yang selama proses pengelasan mengalami siklus termal pemanasan dan pendinginan cepat sehingga daerah ini yang paling kritis dari sambungan las. Secara visual daerah yang dekat dengan garis lebur las maka susunan struktur logamnya semakin kasar.

Pada daerah HAZ terdapat tiga titik yang berbeda, titik 1 dan 2 menunjukkan temperatur pemanasan mencapai daerah berfasa austenit dan ini disebut dengan transformasi menyeluruh yang artinya struktur mikro baja mula-mula ferit+perlit kemudian bertransformasi menjadi austenit $100 \%$. Titik 3 menunjukkan temperatur pemanasan, daerah itu mencapai daerah berfasa ferit dan austenit dan ini yang disebut transformasi sebagian yang artinya struktur mikro baja mula-mula ferit+perlit berubah menjadi ferit dan austenit. 


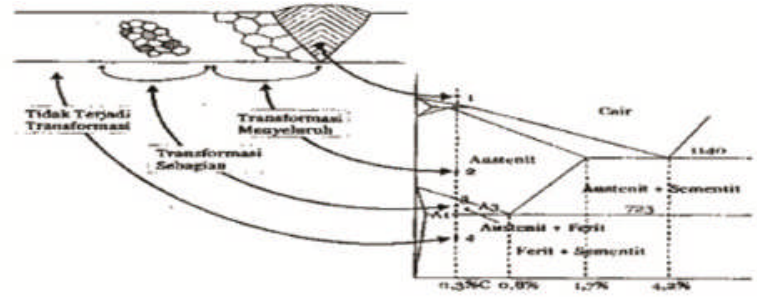

Gambar 2.3 Transformasi Fasa Pada Logam Hasil Pengelasan.

\section{Logam Induk}

Logam induk adalah bagian logam dasar di mana panas dan suhu pengelasan tidak menyebabkan terjadinya perubahan-perubahan struktur dan sifat. Disamping ketiga pembagian utama tersebut masih ada satu daerah pengaruh panas, yang disebut batas las.
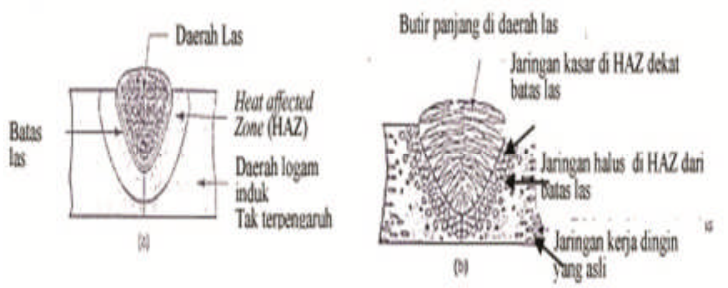

\section{Gambar 2.4 Perubahan Sifat Fisis Pada Sambungan Las Cair}

\section{Diagram CCT (Continuous Cooling Transformation)}

Pada proses pengelasan, transformasi austenit menjadi ferit merupakan tahap yang paling penting karena akan mempengaruhi struktur logam las, hal ini disebabkan karena sifat-sifat mekanis material ditentukan pada tahap tersebut.Faktorfaktor yang mempengaruhi transformasi austenit menjadi ferit adalah masukan panas, komposisi kimia las, kecepatan pendinginan dan bentuk sambungan las.

Struktur mikro dari baja pada umumnya tergantung dari kecepatan pendinginannya dari suhu daerah austenit sampai suhu kamar. Karena perubahan struktur ini maka dengan sendirinya sifat-sifat mekanik yang dimiliki baja juga akan berubah. Hubungan antara kecepatan pendinginan dan struktur mikro yang terbentuk biasanya digambarkan dalam diagram yang menghubungkan waktu, suhu dan transformasi, diagram tersebut dikenal dengan diagram CCT (continuous cooling

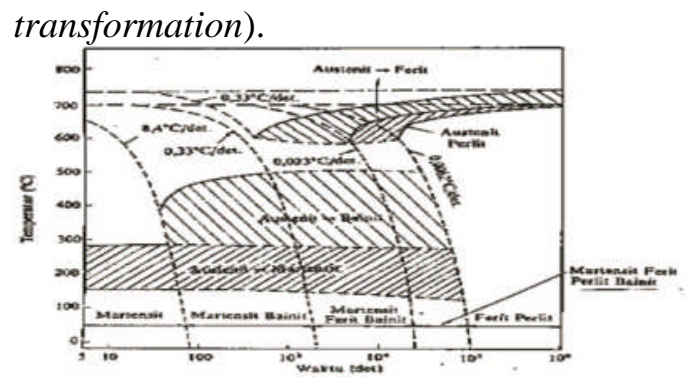

Gambar 2.5 Diagram CCT Baja ASTM 4340 Contoh diagram CCT ditunjukkan dalam gambar di atas, dari diagram di atas dapat dilihat bahwa bila kecepatan pendinginan naik berarti waktu pendinginan dari suhu austenit turun, struktur akhir yang terjadi berubah campuran ferit-perlit ke campuran ferit-perlit-bainit-martensit,ferit-bainitmartensit, kemudian bainit-martensit dan akhirnya pada kecepatan yang tinggisekali struktur akhirnya adalah martensit.

\section{Cacat - Cacat Las Dalam Pengelasan}

Sangatlah penting memahami dan mengerti proses yang mempengaruhi proses pengelasan. Namun sangatlah penting juga untuk mengetahui cacat apa saja yang ada setelah proses welding .Cacat las / defect welding adalah suatu keadaan hasil pengelasan dimana terjadi penurunan kualitas dari hasil lasan. Kualitas hasil lasan yang dimaksud adalah berupa turunnya kekuatan dibandingkan dengan kekuatan bahan dasar base metal, tidak baiknya performa / tampilan dari suatu hasil las atau dapat juga berupa terlalu tingginya kekuatan hasil lasan sehingga tidak sesuai dengan tuntutan kekuatan suatu konstruksi. Terjadinya cacat las ini akan mengakibatkan banyak hal yang tidak diinginkan dan mengarah pada turunnya tingkat keselamatan kerja, baik keselamatan alat, pekerja, lingkungan dan perusahaan. Di samping itu juga secara ekonomi akan mengakibatkan melonjaknya biaya produksi dan akan mengakibatkan kerugian. Menurut American Socety Mechanical Engineers( ASME ), penyebab cacat lasan dapat dibagi menjadi beberapa faktor antara lain :

1. Kurang mendukungnya lokasi pengerjaan

2. Kesalahan operator

3. Kesalahan teknik pengelasan

4. Kesalahan material

Berikut ini adalah analisa cacat welding yang didapat setelah proses pengelasan :

\section{Macam-macam jenis cacat las}


Ada beberapa macam jenis cacat las yang ditimbulkan setelah proses welding cacat tersebut meliputi :

\section{Cacat las bagian luar}

Cacat las bagian luar diantaranya :

\section{A. Takikan bawah (undercut)}

Cacat las ini diakibatkan oleh penggunaan parameter las yang kurang tepat, khususnya kecepatan pengelasan yang terlalu tinggi.Untuk permasalahan seperti ini kita dapat mengurangi kecepatan agar cacat undercutting dapat berkurang.Dan lakukan kontak tube, nozzle.

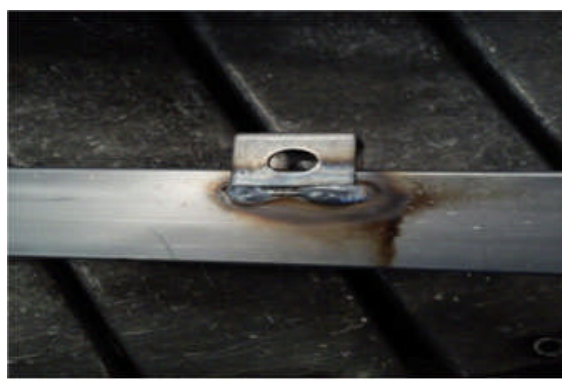

Gambar 2.6 Cacat Las under cut

Penumpukan logam las

Artinya yaitu logam las banyak yang menumpuk pada sisi jalur las. Ciri-cirinya adalah pada sisi jalur las tidak terjadi pencairan yang sempurna sehingga logam las hanya menempel pada logam dasarnya ( ngelipat ).

\section{Porosity}

Porosity adalah lubang diakibatkan oleh gelembung las yang ditemukan didalam welding bead yang telah membeku. Penyebab utama dari porositi adalah kontaminasi atmosfir dapat diakibatkan oleh : kurangnya aliran gas pelindung, aliran gas pelindung yang berlebihan, adanya kerusakan pada perlatan pelindung dan adanya angin di area kerja ( kipas angin )

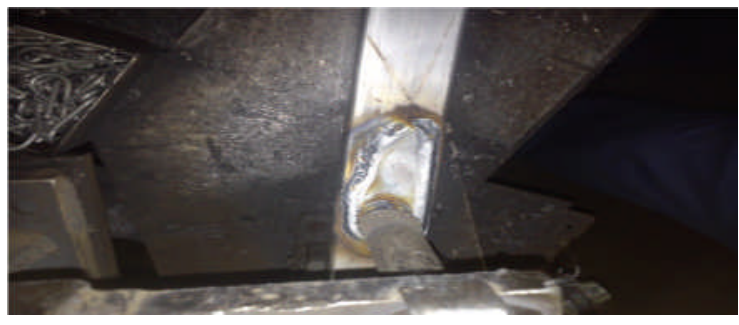

Gambar 2.7 Cacat las porositi

\section{Kurang pencairan}

Kurang pencairan mengakibatkan hasil welding kurang kuat.Biasanya kurang pencairan dapat diatasi dengan menambah voltage nya.

\section{Cacat bagian dalam}

Cacat las bagian dalam hasil pengelasan di antaranya adalah

Slag inclution

Bila logam yang dilas tidak di bersihkan dahulu, maka akan terjadi kontaminasi pada logam las kotoran kotoran yang menyebabkan hasil las menjadi kotor yaitu karat, oli, grease, debu, dan lain-lain. Untuk mencegah keadaan tersebut maka sebelum melakukan pengelasan benda kerja harus dibersihkan.

Retak (cracking)

Tanda-tanda pengelasan yang retak, yaitu pada permukaan logam terlihat pecah-pecah.

Penetrasi tidak sempurna.

\section{Cacat penyimpangan dimensi}

Selain cacat yang ada di atas adapula cacat penyimpangan dimensi. Cacat penyimpangan dimensi yaitu apabila kerangka motor yang sudah finish / sudah melalui proses welding ini menyimpang ketika di lakukan pengecekan ( jig inspection).

Atau dengan kata lain kerangka motor ini tidak masuk dalaam inspection jig. Cacat penyimpangan dimensi biasanya bisa berasal dari kesalahan assembling ataupun material yang variasi menurut ukuran dan ada permasalahan pada jig proses.

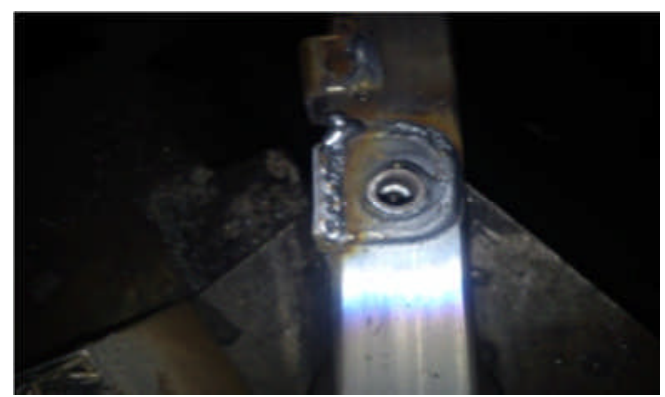

Gambar 2.8 Cacat Las ( keropos ) dan Cacat Penyimpangan Dimensi

\section{Pengujian Hasil Las}

Pengujian pengelasan sangatlah penting dalam proses pengelasan. Dengan pengujian pengelasan maka kita akan mengetahui apakah hasil las an memang sudah di katakana OK dan siap untuk di gunakan. Karena jika memang hasil las an kurang bagus dan dipaksakan untuk di gunakan dalam konstruksi maka akan berakibat fatal bagi pengguna. Berikut ini kita akan membahas lebih dalam mengenai pengujian dalam proses pengelasan.

Pengujian dan pemeriksaan hasil las 
Hasil pengelasan pada umumnya sangat bergantung pada keterampilan juru las.Kerusakan hasil las baik di permukaan maupun di bagian dalam sulit dideteksi dengan metode pengujian sederhana. Selain itu karena struktur yang dilas merupakan bagian integral dari seluruh badan material las maka retakan yang timbul akan menyebarluas dengan cepat bahkan mungkin bisa menyebabkan kecelakaan yang serius. Untuk mencegah kecelakaan tersebut pengujian dan pemeriksaan daerah-daerah las sangatlah penting.

Tujuan dilakukannya pengujian adalah untuk menentukan kualitas produk-produk atau spesimen-spesimen tertentu, sedangkan tujuan pemeriksaan adalah untuk menentukan apakah hasil pengujian itu relatif dapat diterima menurut standar - standar kualitas tertentu atau tidak dengan kata lain tujuan pengujian dan pemeriksaan adalah untuk menjamin kualitas dan memberikan kepercayaan terhadap konstruksi yang dilas.

\section{Klasifikasi metode pengujian hasil pengelasan}

Metode pengujian daerah las secara kasar dapat diklasifikasikan menjadi pengujian merusak / destruktif (DT) dan pengujian tidak merusak / nondestruktif (NDT).Dalam pengujian destruktif, sebuah spesimen atau batang uji dipotongkan dari daerah las atau sebuah model berukuran penuh dari daerah las yang diuji dilakukan perubahan bentuk dengan dirusak untuk menguji sifat-sifat mekanik dan penampilan daerah las tersebut.Dalam pengujian non-destruktif, hasil pengelasan diuji tanpa perusakan untuk mendeteksi kerusakan hasil las dan cacat dalam. Klasifikasi metode pengujian daerah las :

\section{Pengujian dengan cara merusak}

1. UJi tarik

Uji tarik dilaksanakan untuk menentukan kekuatan tarik, titik mulur (kekuatan lentur) las, pemanjangan dan pengurangan material las. Spesimen tersebut ujung-ujungnya dipegang dengan jepitan alat penguji, dan ditarik dengan menggunakan beban

2. Uji lengkung

Uji lengkung dilaksanakan untuk memeriksa pipa saluran dan keutuhan mekanis dari material las. Ada dua jenis uji lengkung, yaitu: uji lengkung kendali dan uji lengkung gulungan. Pada tiap-tiap jenis uji lengkung itu, sebuah spesimen dalam bentuk dan ukuran tertentu dilengkungkan sampai radius bagian dalam tertentu dan sudut lengkung tertentu, kemudian diperiksa keretakan dan kerusakannya
3. Uji Hentakan

Uji hentakan dilaksanakan untuk menentukan kekuatan material las. Sebagai sebuah metode uji hentakan yang digunakan di dalam dunia industri, JIS menetapkan secara khusus uji hentakan charpy dan uji hentakan izod

\section{Uji Kekerasan}

Uji kekerasan, seperti halnya uji tarik, seringkali dilaksanakan. Karena daerah las dipanaskan dan didinginkan dengan cepat, maka daerah yang terkena panas akan menjadi keras dan rapuh. Kekerasan maksimal pada daerah las yang diukur dengan uji kekerasan digunakan sebagai dasar penentuan kondisi-kondisi sebelum dan sesudah pemanasan yang akan dilakukan untuk mencegah retakan hasil pengelasan

\section{Uji struktur}

Uji struktur mempelajari struktur material logam.Untuk keperluan pengujian, material logam dipotong-potong, kemudian potongan - potongan diletakkan di bawah dan dikikis dengan material alat penggores yang sesuai.Uji struktur ini dilaksanakan secara makroskopik atau mikroskopik.Dalam uji makroskopik, permukaan spesimen diperiksa dengan mata telanjang atau melalui loupe untuk mengetahui status penetrasi, jangkauan yang terkena panas, dan kerusakannya.Dalam pemeriksaan mikroskopik, permukaan spesimen diperiksa melalui mikroskop metalurgi untuk mengetahui jenis struktur dan rasio komponen-komponennya, untuk menentukan sifat-sifat materialnya.

\section{Pengujian dengan cara tak merusak ( NDT )}

\section{Uji visual ( VT )}

Uji visual merupakan salah satu metode pemeriksaan terpenting yang paling banyak digunakan.Uji visual tidak memerlukan peralatan tertentu dan oleh karenanya relatif murah selain juga cepat dan mudah dilaksanakan.

\section{Uji Partikel Magnet ( MT )}

Pengujian terhadap partikel magnet merupakan metode yang benar-benar efisien dan mudah dilaksanakan untuk mendeteksi secara visual kerusakan-kerusakan halus yang tidak teridentifikasi pada atau di dekat permukaan logam.

\section{Uji Zat Penetran (PT)}

Pada umumnya, uji zat penetran ini dilakukan secara manual, sehingga dapat tidaknya kerusakan itu berhasil dideteksi sangat bergantung pada ketrampilan penguji. 
Kita sudah mengetahui beberapa macam pengujian setelah proses pengelasan. Pengujian - pengujian tersebut biasa di gunakan dalam menentukan status hasil welding. Namun dalam hal ini kita akan membahas lebih dalam mengenai uji makro. Agar kita mengetahui lebih tentang uji makro mari kita bahas bersama di halaman selanjutnya.

\section{METODE PENELITIAN}

Persiapan

Tahapan ini adalah tahapan menentukan benda mana yang akan di uji dan selain itu juga tahapan ini adalah tahapan mempersiapkan alat - alat yang di perlukan dalam pengujian mikro.

\section{Pengelasan}

Tahap ini merupakan tahap pengelasan benda uji. Dimana kita akan menggunakan material pipa dengan tipe STKM 11A untuk pengelasan link engine hanger dan kawat las ( flux ) yang di gunakan adalah kawat las ER 70S 6 berdiameter $1.2 \mathrm{~mm}$.

Sesuai dengan klasifikasi elektroda menurut AWS A5.18-93,penomoranya sebagai berikut :

$$
\text { ER XXS - X }
$$

Keterangan symbol di atas adalah :

$\begin{array}{ll}\mathrm{ER} & =\text { elektroda atau welding rod } \\ \mathrm{XX} & =\text { kekuatan tarik } \\ \mathrm{S} & =\text { solid atau rod } \\ \mathrm{X} & =\text { komposisi kimia }\end{array}$

Elektroda pada kelas ini memiliki kandungan silikon terbesar $(1,15 \%)$ dan mangan yang besar $(1,85 \%)$ sebagai element deoksidasi. Pada umumnya untuk baja karbon rendah menggunakan gas pelindung $\mathrm{CO} 2$ dan arus listrik

Gambar 3.1 Tong kawat las ( elektroda )

Sebelum kita melakukan proses pengelasan hal yang harus dilakukan adalah menyiapkan bahan dan alat nya, Berikut ini adalah tahap persiapandalam proses pengelasan :

bahan dan alat yang di gunakan dalam proses pengelasan :
1. Pipa dengan jenis STKM 11A dan part part pendukung lainya untuk jenis pengelasan link engine hanger.

2. Jig proses

3. Robot welding

4. Serta peralatan pengelasan meliputi : adaptor, electrode berdiameter 1.2, gas pelindung, serta kelengkapan lainya.

5. APD atau biasa di sebut alaat pelindung diri meliputi :hand protector, body protector, sarung tangan, safety shoes serta kelengkapan lainya.

Setelah kita sudah menyiapkan bahan serta alat pengelasan maka tahap selanjutnya adalah tahap pengelasan benda uji. Di sini kita akan membuat 15 sample barang dengan masing masing 5 sample untuk 3 sudut kerja pengelasan yang berbeda. Di antaranya adalah sudut kerja $75^{\circ}, 45^{\circ}$, $30^{\circ}$. Mengenai gambar sudut kerja dan proses pengelasan nya bisa kita lihat di bawah ini :

\section{Proses pengelasan}

\section{Sudut kerja pengelasan $75^{\circ}$}

1. Pasang material pipa dengan jenis STKM 11A pada jig.

2. Pastikan sudut kerja pengelasan adalah sudut kerja $75^{\circ}$ ( pada pengaturan ini kita perlu mengubah parameter welding khususnya electrode work angle ) biasanya proses setting ini di lakukan oleh seorang programmer.

3. Jika sudah di pastikan sudut kerja sesuai maka proses welding bisa di lakukan dengan memencet tombol on yang ada pada area welding robotic.

Sudut kerja pengelasan $45^{\circ}$

1. Pasang material pipa dengan jenis STKM 11A pada jig.

2. Pastikan sudut kerja pengelasan adalah sudut kerja $45^{\circ}$ ( pada pengaturan ini kita perlu mengubah parameter welding khususnya electrode work angle ) biasanya proses setting ini di lakukan oleh seorang programmer.

3. Jika sudah di pastikan sudut kerja sesuai maka proses welding bisa di lakukan dengan memencet tombol on yang ada pada area welding robotic.

Sudut kerja pengelasan $30^{\circ}$

1. Pasang material pipa dengan jenis STKM 11A pada jig. 
2. Pastikan sudut kerja pengelasan adalah sudut kerja $30^{\circ}$ ( pada pengaturan ini kita perlu mengubah parameter welding khususnya electrode work angle ) biasanya proses setting ini di lakukan oleh seorang programmer.

3. Jika sudah di pastikan sudut kerja sesuai maka proses welding bisa di lakukan dengan memencet tombol on yang ada pada area welding robotic.

Setelah kita melakukan proses welding maka proses atau tahapan selanjutnya adalah tahapan pembentukan benda uji atau biasa di sebut dengan proses cutting ( pemotongan ) namun sebelum proses pemotongan kita perlu melewati uji visual welding.

\section{ANALISA DAN PEMBAHASAN}

Pada bab sebelumnya penulis sudah menyampaikan tentang metodologi penelitian yang berisi tentang diagram alir dan uraian tahaptahap dalam pengujian yaitu; tahap studi literatur dan studi lapangan, tahap penyiapan bahan dan alat kerja, tahap pembuatan spesimen, tahap pelaksanaan pengujian dan tahap pengambilan data hasil pengujian.

Pada bab ini penulis akan lebih membahas tentang welding inspection standars dalam proses welding link engine hanger pada type K16 ( Honda Beat ) dan hasil pengujian - pengujian dari proses peengelasan dengan variasi sudut pengelasan $30^{\circ}$, $45^{\circ}$ dan $75^{\circ}$

Sebelum kita membahas tentang data data hasil pengujian, Hendaknya kita mengetahui welding inspection standard dalam proses welding yang ada di PT. Astra Honda Motor dan PT. Pamindo Tiga $\mathrm{T}$ berdasarkan AWS. Berikut ini adalah Welding inspection standard yang ada di PT. Astra Honda Motor dan PT. Pamindo Tiga T :

Untuk data - data uji mikro pada pengelasan dengan menggunakaan sudut kerja $75^{\circ}, 45^{\circ}$ dan $30^{\circ}$ dapat kita lihat di bawah ini :
- part name
: Link engine hanger
○ type
- Material
: K16
○ Robot
: STKM 11A
- Programer
: Panasonic RW 106
- Tebal material dasar : $2.6 \mathrm{~mm}$
○ Pengelasan : Robotic
- Ampere : $: 210$
○ Voltage : 19.5
$\circ$ Wire diameter $\quad: 1.2 \mathrm{~mm}$

- Dengan 3 Sudut kerja: $30^{\circ}, 45^{\circ}$ dan $75^{\circ}$
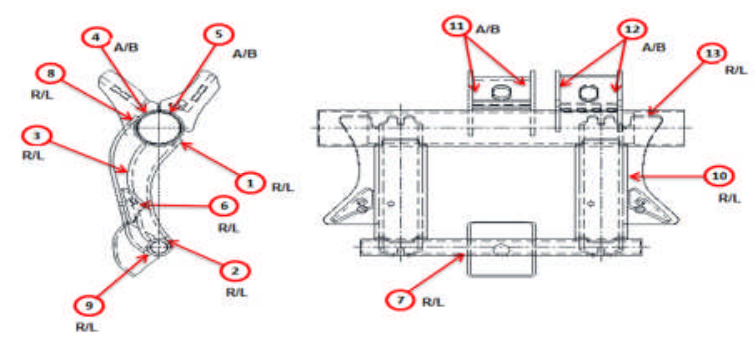

KETERANGAN :

1. BRACKET UPPER + PIPE (R/L)

2. BRACKET UPPER + COLLAR (R/)

3. BRACKET UPPER + BRACKET LOWER (R/L)

4. STAY STOPPER + PIPE (AVB)

5. STAY STOPPER + PIPE (AVB)

6. PLATE GUARD + BRACKET LOWER + GUARD ENG HANGER (R/L)

7. GUARD CTR ENG HANGER + COLLAR (R/L)

8. BRACKET LOWER + PIPE (R/L)

9. BRACKET LOWER + COLLAR (R/L)

10. GUARD ENG HANGER + BRACKET LOWER ( R/L )

11. STAY STOPPER + PLATE STOPPER (ANB)

12. STAY STOPPER + PLATE STOPPER (
13.PIPE + GUARD ENG HANGER (R/ )

\section{Gambar . 4.1 link engine hanger}

Note : point no 5 adalah point yang di foto mikro

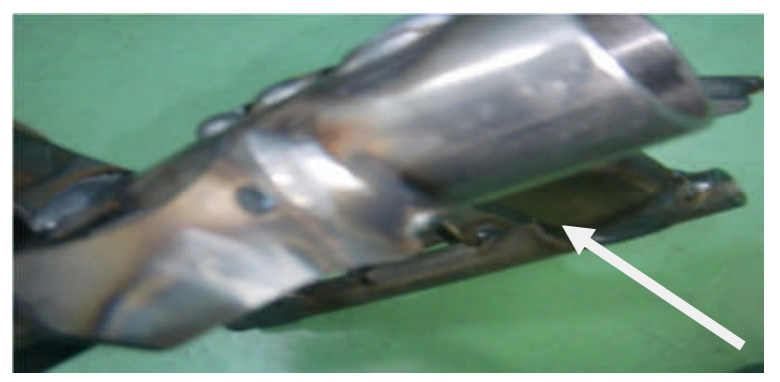

Gambar. 4.2 stay stopper dan pipa

Berikut ini adalah judgement menurut standart welding AWS dari PT. Astra Honda Motor yang digunakan untuk pengujian makro kali ini adalah sebagai berikut :

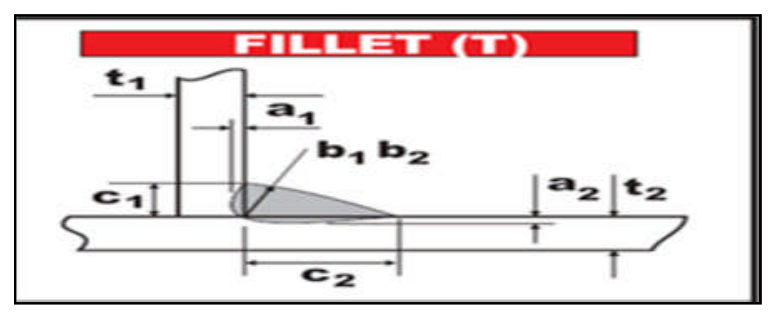

Gambar.4.3 Judgement fillet.

Dalam pengujian makro kali ini kita meneliti link engine hanger jenis K16 honda beat dengan jenis material pipa STKM 11A dan dengan menggunakan robot welding Panasonic RW 106 dalam pengujian ini ada seorang programmer yang nantinya akan bertugas merubah settingan sudut kerja pengelasan mulai dari sudut $30^{\circ}, 45^{\circ}$ dan 
$75^{\circ}$ dari hasil proses pengelasan ini nantinya akan di gunakan untuk uji mikro dengan judgement fillet ( F ) Pada standard welding inspection material tipis di lambangkan dengan $\mathrm{t} 1$, dan material tebal di lambangkan dengan t2. Dalam proses pengelasan material pengisi harus memakan sebagian dari tebal material asli 1 dan tebal material asli 2. Biasanya jarak jangkauan pemakanan material ini dinamakan a1 dan a2.Dimana a1 adalah jarak dimana material pengisi memakan sebagian dari tebal material asli 1 atau t1.Dan a2 sendiri adalah jarak dimana material pengisi memakan sebagian dari tebal material asli 2 atau t2.Dan selain itu ada c1 dan c2 dimana c1 adalah panjang material pengisi dari titik pusat sampai titik atas pada material 1.( pada gambar judgement ).

Dan c2 sendiri adalah panjang pengelasan dari titik pusat sampai titik akhir dimana material pengisi terlihat pada t2.Dan ada pula b1 dan b2, b1 dan b2 di sini adalah kerongkongan pengelasan. Dimana di sini di lakukan penarikaan ukuran dari titik pusat menuju ke bagian paling luar dari material pengisi ( lihat gambar 4.3 ).

Untuk hasil hasil uji mikro tiap sudutnya bisa kita di lihat di bawah ini :

\section{Uji Mikro sudut kerja pengelasan $30^{\circ}$}

Pada sudut kerja pengelasan $30^{\circ}$ kali ini penulismenggunakan pengelasan robot Panasonic RW 106, dan menggunakan ampere 210 A, voltage $19.5 \mathrm{v}$, speed $0.70 \mathrm{~mm} / \mathrm{menit}$, menggunakan gas pelindung CO2 dengan diameter kawat las $1.2 \mathrm{~mm}$ jenis tipe kawat las adalah ER 70 ES. Pada penelitian sudut ini penulis harus memastikan bahwa sudut kerja pengelasan berada di kisaran $30^{\circ}$.setelah semua parameter pengelasan di pastikan sudah baik. Maka proses selanjutnya adalah proses pengelasan.

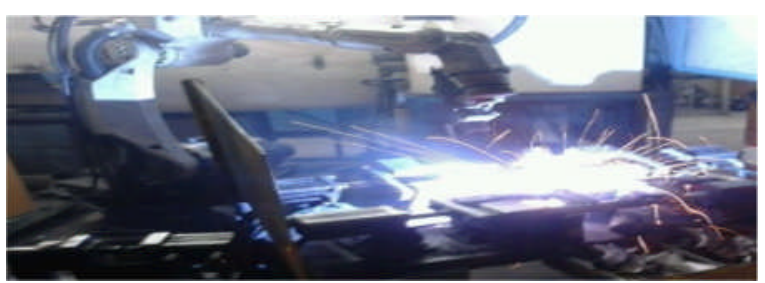

Gambar 4.4 proses pengelasan link engine hanger type $k 16$

Dari hasil pengelasan ini maka penulis akan memperoleh bahan uji yaitu adalah link engine hanger. Berikut ini adalah gambar bahan yang akan di uji mikro

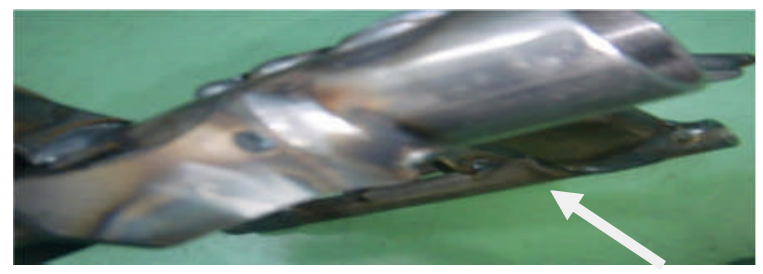

Gambar 4.5 stay stopperdan pipalinkengine hanger tipe $k 16$

Setelah proses pengelasan di lakukan maka langkah selanjutnya adalah uji visual dimana penulis akan melihat apakah ada cacat las ataupun tidak dan dilanjutkan dengan proses pembentukan benda uji. Biasanya pembentukan benda uji dan pengetsaan di lakukan setelah material atau bahan uji lolos dari uji visual.

Pada pengujian mikro kali ini peneliti menggunakan standard kebertrimaan, berdasar AWS D1.1 dan inspection welding standard yang ada di PT. AHM dan PT. Pamindo Tiga T. Dari data - data yang di peroleh dari uji mikro dengan sudut pengelasan $30^{\circ}$ kali ini 5 sample di katakan NG untuk data - data selengkapnya bisa di lihat pada lampiran 2 sampai dengan lampiran 6.

Berikut ini bisa kita lihat sebagian foto dari hasil uji mikro :

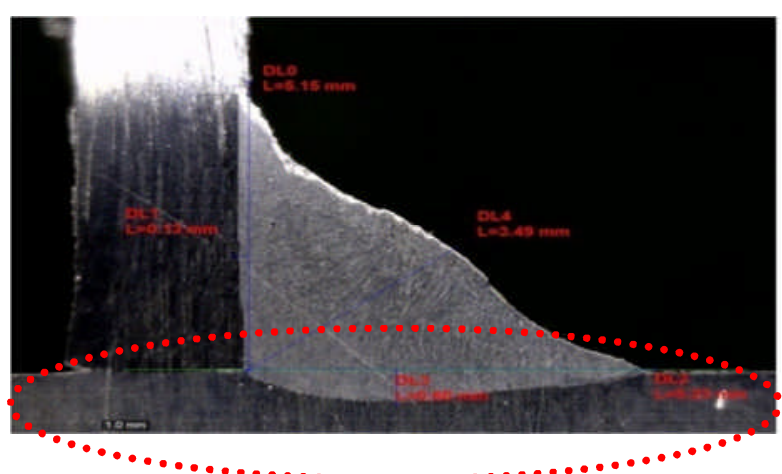

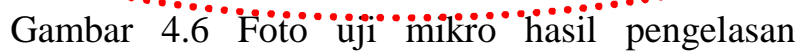
dengan sudut $30^{\circ}$

Hasil uji makro di katakan NG karena a1 tidak memenuhi referensi standard welding inspection untuk judgement fillet. Karena setelah di adakan uji mikro dari 5 sample ini ukuran actual nya kurang dari ukuran refferensi standard yang ada. Maka untuk pengelasan link engine hanger type K16 dengan jenis material STKM 11A hendaknya tidak menggunakan sudut kerja $30^{\circ}$.Karena jika memang hasil las an kurang bagus dan dipaksakan untuk di gunakan dalam konstruksi maka akan 
berakibat fatal bagi pengguna. Yang berakibat akan terjadinya accident.

\section{Uji Mikro sudut kerja pengelasan $\mathbf{4 5}^{\circ}$}

Pada sudut kerja pengelasan $45^{\circ}$ kali ini penulis menggunakan pengelasan robot Panasonic RW 106, dan menggunakan ampere 210 A, voltage $19.5 \mathrm{v}$, speed $0.70 \mathrm{~mm} /$ menit, menggunakan gas pelindung $\mathrm{CO} 2$ dengan diameter kawat las $1.2 \mathrm{~mm}$ jenis tipe kawat las adalah ER 70 ES. Pada penelitian sudut ini penulis harus memastikan bahwa sudut kerja pengelasan berada di kisaran $45^{\circ}$.setelah semua parameter pengelasan di pastikan sudah baik. Maka proses selanjutnya adalah proses pengelasan.

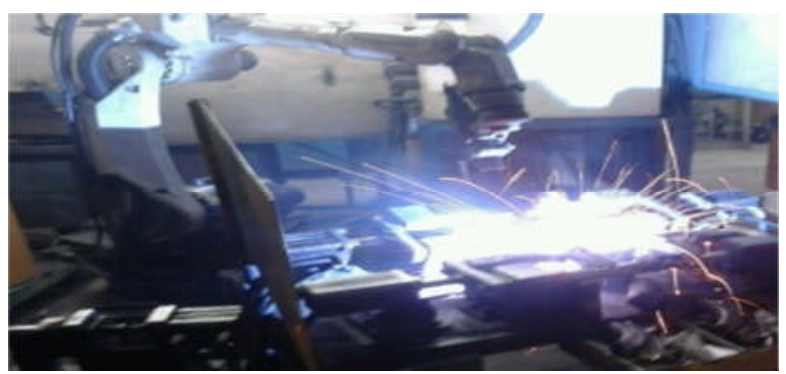

Gambar 4.7 proses pengelasan link engine hanger type $k 16$

Dari hasil pengelasan ini maka penulis akan memperoleh bahan uji yaitu adalah link engine hanger type K16. Berikut ini adalah gambar bahan yang akan di uji mikro

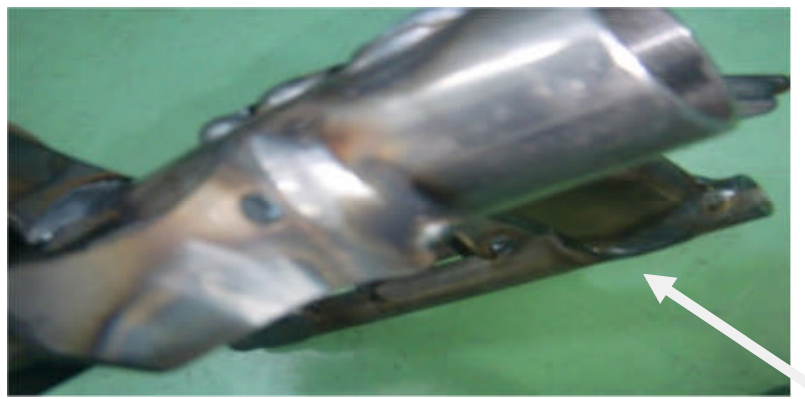

Gambar 4.8 stay stopper dan pipa

Setelah proses pengelasan di lakukan maka langkah selanjutnya adalah uji visual dimana penulis akan melihat apakah ada cacat las ataupun tidak dan dilanjutkan dengan proses pembentukan benda uji. Biasanya pembentukan benda uji dan pengetsaan di lakukan setelah material atau bahan uji lolos dari uji visual. Pada pengujian makro kali ini peneliti menggunakan judgement fillet, berdasar dari AWS D1.1 dan inspection welding standard yang ada di PT. AHM dan PT. Pamindo Tiga T.
Dari data - data yang di peroleh dari uji mikro dengan sudut pengelasan $45^{\circ}$ kali ini 5 sample di katakan OK dimana ukuran actual yang di dapat memenuhi ukuran standard referensi welding. Untuk hasil foto mikro bisa dilihat di bawah ini :

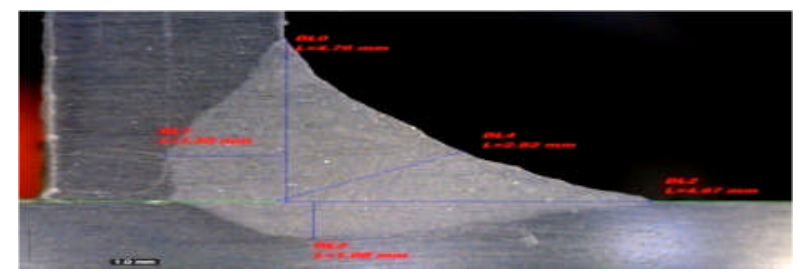

Gambar 4.9 Hasil uji mikro sudut pengelasan $45^{\circ}$

Dari gambar 4.7 di atas bisa di lihat bahwa material pengisi memakan sebagian dari material asli. Untuk data - data selengkapnya bisa di lihat pada lampiran 7 sampai dengan lampiran 11 .jadi untuk pengelasan link engine hangertype K16 dengan jenis material STKM 11A hendaknya menggunakan sudut kerja $45^{\circ}$

\section{Uji Mikro sudut kerja pengelasan $75^{\circ}$}

Pada sudut kerja pengelasan $75^{\circ}$ kali ini penulis menggunakan pengelasan robot Panasonic RW 106, dan menggunakan ampere 210 A, voltage $19.5 \mathrm{v}$, speed $0.70 \mathrm{~mm} /$ menit, menggunakan gas pelindung $\mathrm{CO} 2$ dengan diameter kawat las $1.2 \mathrm{~mm}$ jenis tipe kawat las adalah ER 70 ES. Pada penelitian sudut ini penulis harus memastikan bahwa sudut kerja pengelasan berada di kisaran $75^{\circ}$.setelah semua parameter pengelasan di pastikan sudah baik. Maka proses selanjutnya adalah proses pengelasan

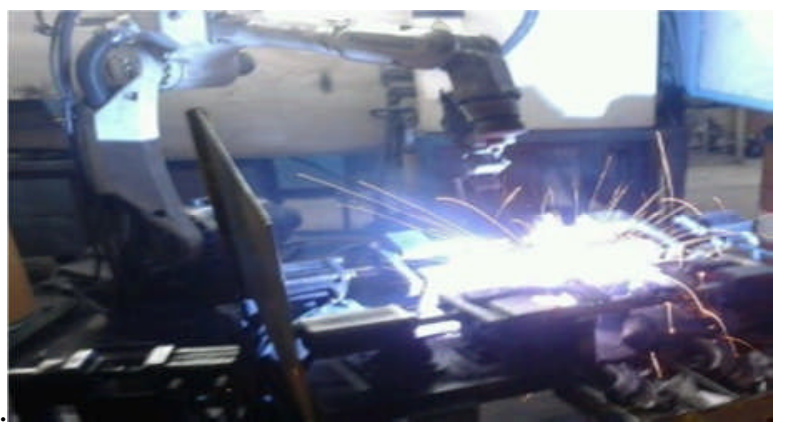

Gambar 4.10 proses pengelasan link engine hanger type $k 16$

Dari hasil pengelasan ini maka penulis akan memperoleh bahan uji yaitu adalah link engine hanger type K16. Berikut ini adalah gambar bahan yang akan di uji makro 


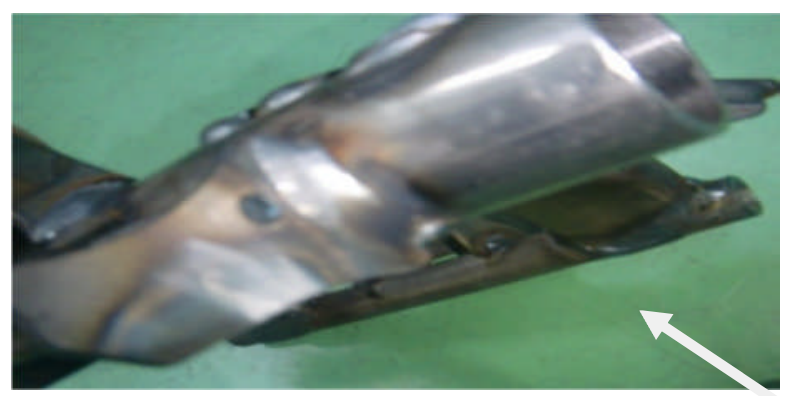

Gambar 4.11 stay stopperdan pipa

Setelah proses pengelasan di lakukan maka langkah selanjutnya adalah uji visual dimana penulis akan melihat apakah ada cacat las ataupun tidak dan dilanjutkan dengan proses pembentukan benda uji. Biasanya pembentukan benda uji dan pengetsaan di lakukan setelah material atau bahan uji lolos dari uji visual.

Pada pengujian mikro kali ini peneliti menggunakan judgement fillet, berdasar dari AWS D1.1 dan inspection welding standard yang ada di PT. AHM dan PT. Pamindo Tiga T. Dari data data yang di peroleh dari uji mikro dengan sudut pengelasan $75^{\circ}$ kali ini 5 sample di katakana NG untuk data - data selengkapnya bisa di lihat pada lampiran 12 sampai dengan lampiran 16. Untuk sebagian hasil dari foto mikro bisa kita lihat di bawah ini :

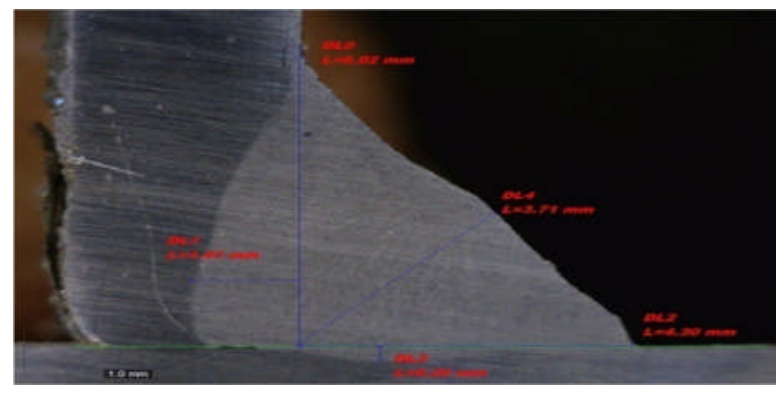

Gambar 4.12 Foto uji mikro hasil pengelasan dengan sudut $75^{\circ}$

Hasil uji makro di katakan NG karena a2 tidak memenuhi referensi standard welding inspection untuk judgement fillet. Karena setelah di adakan uji mikro dari 5 sample ini ukuran actual nya kurang dari ukuran refferensi standard yang ada. Maka untuk pengelasan link engine hanger type K16 dengan jenis material STKM 11A hendaknya tidak menggunakan sudut kerja $75^{\circ}$.

\section{Analisa Hasil Uji Mikro}

Pada standard welding inspection material tipis di lambangkan dengan $\mathrm{t} 1$, dan material tebal di lambangkan dengan t2. Dalam proses pengelasan material pengisi harus memakan sebagian dari tebal material asli 1 dan tebal material asli 2 . Biasanya jarak jangkauan pemakanan material ini dinamakan a1 dan a2.Dimana a1 adalah jarak dimana material pengisi memakan sebagian dari tebal material asli 1 atau t1.Dan a2 sendiri adalah jarak dimana material pengisi memakan sebagian dari tebal material asli 2 atau t2.Dan selain itu ada c1 dan c2 dimana c1 adalah panjang material pengisi dari titik pusat sampai titik atas pada material 1.( pada gambar judgement ).

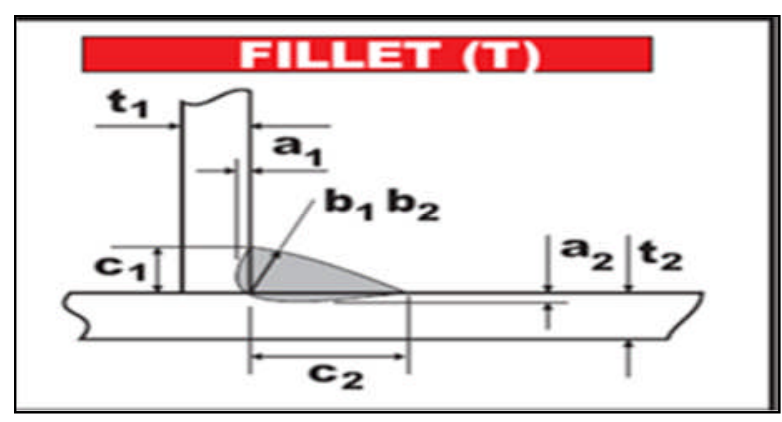

Gambar.4.13 Judgement fillet.

Dan c2 sendiri adalah panjang pengelasan dari titik pusat sampai titik akhir dimana material pengisi terlihat pada $t 2$.Dan ada pula $b 1$ dan $b 2, b 1$ dan b2 di sini adalah kerongkongan pengelasan. Dimana di sini di lakukan penarikaan ukuran dari titik pusat menuju ke bagian paling luar dari material pengisi ( lihat gambar 4.6 ). ketika material pengisi tidak memakan sebagian dari tebal material asli 1 ( t1 ) dan tebal material $2(\mathrm{t} 2)$ otomatis hasil pengelasan di katakan NG. karena ketika proses uji makro ukuran actual nya tidak memenuhi standard welding inspection maka bisa di pastikan kekuatan pengelasan tidak kuat. Dan bisa berpotensi material yang di sambung atau di las bisa copot lagi.

Dari data yang di peroleh dari penelitian bahwa dari ketiga sudut kerja pengelasan yang paling sempurna adalah sudut kerja $45^{\circ}$,

Dimana dari 5 sample pengujian sudut kerja pengelasan $75^{\circ}$ terjadi NG pada a2dimana actual dari a2 tidak memenuhi referensi standart welding inspection, sedangkan dari sudut kerja pengelasan $30^{\circ}$ hasil uji mikro nya masuk kategori NG dimana actual dari al tidak memenuhi referensi standart welding inspection dengan judgement fillet $(F)$.

\section{Hasil Uji Kekerasan}


Pengujian ini menggunakan 3 buah spesimen yaitu dengan sudut pengelasan $30^{\circ} 45^{\circ}$ dan $75^{\circ}$ dengan spesifikasi seperti berikut :

- Tebal material dasar : $2.6 \mathrm{~mm}$

- Pengelasan : Robotic

- Ampere : 210

$\circ$ Voltage : 19.5

○ Wire diameter $\quad: 1.2 \mathrm{~mm}$

$\circ$ dengan ukuran spesimen 50 x $100 \mathrm{~mm}$

Tabel 4.1 Hasil Pengujian Kekerasan vikers dalam satuan $\mathrm{kg} / \mathrm{mm}^{2}$ untuk sudut $30^{\circ}$

\begin{tabular}{|c|c|c|c|c|c|c|c|}
\hline & & & & & & erja pengel & $\operatorname{las} 33^{\circ}$ \\
\hline No & Daerah & $\begin{array}{l}\text { Posisi } \\
(\mathrm{mm})\end{array}$ & $\begin{array}{c}D \\
(\mu \mathrm{m})\end{array}$ & $\begin{array}{c}D 1 \\
(\mu \mathrm{m})\end{array}$ & $\begin{array}{c}D 2 \\
(\mu \mathrm{m})\end{array}$ & HVN & Rata - rata \\
\hline 1 & \multirow{3}{*}{ lasan } & 0.15 & 182 & 91 & 91 & 22.39 & \multirow{3}{*}{25.88} \\
\hline 2 & & 0.25 & 160 & 80 & 80 & 28.97 & \\
\hline 3 & & 0.35 & 168 & 84 & 84 & 26.28 & \\
\hline 4 & Batas & 0.45 & 173 & 86.5 & 86.5 & 24.78 & \\
\hline 5 & \multirow{4}{*}{ HAZ } & 0.55 & 138 & 69 & 69 & 38.94 & \multirow{4}{*}{38.4} \\
\hline 6 & & 0.65 & 142 & 71 & 71 & 36.78 & \\
\hline 7 & & 0.85 & 138 & 69 & 69 & 38.94 & \\
\hline 8 & & 1.05 & 138 & 69 & 69 & 38.94 & \\
\hline 9 & Batas & 1.25 & 150 & 75 & 75 & 32.96 & \\
\hline 10 & \multirow{3}{*}{ logam induk } & 1.45 & 150 & 75 & 75 & 32.96 & \multirow{3}{*}{32.97} \\
\hline 11 & & 1.65 & 152 & 76 & 76 & 32.10 & \\
\hline 12 & & 1.85 & 148 & 74 & 74 & 33.86 & \\
\hline & & & & & & & \\
\hline
\end{tabular}

Gambar diatas menunjukkan tabel nilai kekerasan hasil pengujian dari specimen sudut kerja pengelasan $30^{\circ}$

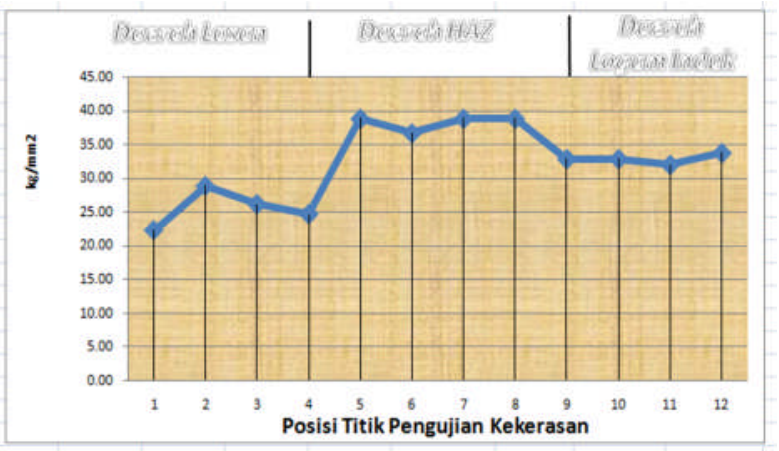

\section{Gambar 4.14 Nilai Kekerasan Hasil Las Dengan Sudut Pengelasan 30}

Gambar diatas menunjukkan bahwa titik 1 sampai dengan 3 adalah nilai kekerasan untuk daerah las, nilai rata - ratanya adalah $25.88 \frac{\mathrm{kg}}{\mathrm{mm}^{2}}$. Titik ke 4 yang terdapat pada grafik menunjukkan nilai kekerasan dari batas daerah lasan dengan daerah HAZ dengan nilai kekerasannya adalah $24.78 \frac{\mathrm{kg}}{\mathrm{mm}^{2}}$. Titik ke 5 sampai 8 merupakan daerah HAZ yang memiliki nilai rata - rata kekerasan sebesar $38.40 \frac{\mathrm{kg}}{\mathrm{mm}^{2}}$. Titik 9 merupakan batas antara daerah HAZ dengan daerah logam induk yang memiliki nilai kekerasan sebesar $32.96 \frac{\mathrm{kg}}{\mathrm{mm}^{2}}$. Titik 10 sampai 12 merupakan daerah logam induk yang memiliki nilai rata - rata kekerasan sebesar 32.97 $\frac{\mathrm{kg}}{\mathrm{mm}^{2}}$. Dari data tabel dan grafik diatas nilai kekerasan tertinggi spesimen dengan variasi sudut pengelasan $30^{\circ}$ berada pada daerah $\mathrm{HAZ}$ yaitu sebesar $38.94 \frac{\mathrm{kg}}{\mathrm{mm}^{2}}$.

\section{Tabel 4.2 Hasil Pengujian Kekerasan vikers dalam satuan $\mathrm{kg} / \mathrm{mm}^{2}$ untuk sudut $4^{\circ}$}

\begin{tabular}{|c|c|c|c|c|c|c|c|}
\hline & & & & & & terja pengel & an $45^{\circ}$ \\
\hline No & Daerah & $\begin{array}{l}\text { Posisi } \\
\text { ( } \mathrm{mm} \text { ) }\end{array}$ & $\begin{array}{c}D \\
(\mu \mathrm{m})\end{array}$ & $\begin{array}{c}\text { D1 } \\
(\mu \mathrm{m})\end{array}$ & $\begin{array}{c}\text { D2 } \\
(\mu \mathrm{m})\end{array}$ & HVN & Rata -rata \\
\hline & \multirow{4}{*}{ lasan } & & & & & & \multirow{4}{*}{27.35} \\
\hline 1 & & 0.15 & 166 & 83 & 83 & 26.91 & \\
\hline 2 & & 0.25 & 164 & 82 & 82 & 27.57 & \\
\hline 3 & & 0.35 & 164 & 82 & 82 & 27.57 & \\
\hline 4 & Batas & 0.45 & 150 & 75 & 75 & 32.96 & \\
\hline 5 & \multirow{4}{*}{ HAZ } & 0.55 & 130 & 65 & 65 & 43.88 & \multirow{4}{*}{43.93} \\
\hline 6 & & 0.65 & 135 & 67.5 & 67.5 & 40.69 & \\
\hline 7 & & 0.85 & 130 & 65 & 65 & 43.88 & \\
\hline 8 & & 1.05 & 125 & 62.5 & 62.5 & 47.46 & \\
\hline 9 & Batas & 1.25 & 145 & 72.5 & 72.5 & \begin{tabular}{|l|l}
35.27 & \\
\end{tabular} & \\
\hline 10 & \multirow{3}{*}{ logam induk } & 1.45 & 149 & 74.5 & 74.5 & 33.40 & \multirow{3}{*}{33.27} \\
\hline 11 & & 1.65 & 150 & 75 & 75 & 32.96 & \\
\hline 12 & & 1.85 & 150 & 75 & 75 & 32.96 & \\
\hline
\end{tabular}

Gambar diatas menunjukkan tabel nilai kekerasan hasil pengujian dari specimen sudut kerja pengelasan $45^{\circ}$

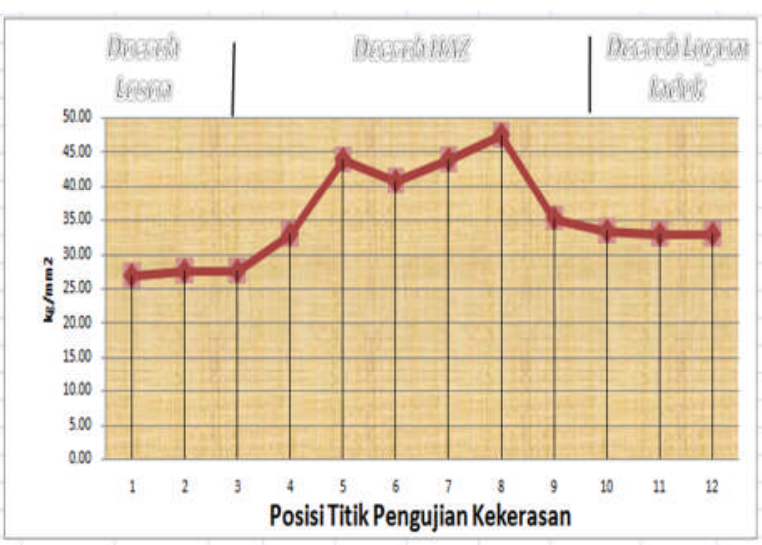

\section{Gambar 4.15 Nilai Kekerasan Hasil Las Dengan Sudut Pengelasan $45^{\circ}$}

Gambar diatas menunjukkan bahwa titik 1 sampai dengan 3 adalah nilai kekerasan untuk daerah las, nilai rata - ratanya adalah $27.35 \frac{\mathrm{kg}}{\mathrm{mm}^{2}}$. Titik ke 4 yang terdapat pada grafik menunjukkan nilai kekerasan dari batas daerah lasan dengan daerah HAZ dengan nilai kekerasannya adalah $32.96 \frac{\mathrm{kg}}{\mathrm{mm}^{2}}$. Titik ke 5 sampai 8 merupakan daerah HAZ yang memiliki nilai rata - rata kekerasan 
sebesar $43.93 \frac{\mathrm{kg}}{\mathrm{mm}^{2}}$. Titik 9 merupakan batas antara daerah HAZ dengan daerah logam induk yang memiliki nilai kekerasan sebesar $35.27 \frac{\mathrm{kg}}{\mathrm{mm}^{2}}$. Titik 10 sampai 12 merupakan daerah logam induk yang memiliki nilai rata - rata kekerasan sebesar 33.27 $\frac{\mathrm{kg}}{\mathrm{mm}^{2}}$. Dari data tabel dan grafik diatas nilai kekerasan tertinggi spesimen dengan variasi sudut pengelasan $45^{\circ}$ berada pada daerah $\mathrm{HAZ}$ yaitu sebesar $47.46 \frac{\mathrm{kg}}{\mathrm{mm}^{2}}$.

Tabel 4.3 Hasil Pengujian Kekerasan vikers dalam satuan $\mathrm{kg} / \mathrm{mm}^{2}$ untuk sudut $\mathbf{7 5}^{\circ}$

\begin{tabular}{|c|c|c|c|c|c|c|c|}
\hline No & Daerah & $\begin{array}{l}\text { Posisi } \\
(\mathrm{mm})\end{array}$ & $\begin{array}{c}D \\
(\mu \mathrm{m})\end{array}$ & $\begin{array}{c}D 1 \\
(\mu \mathrm{m})\end{array}$ & $\begin{array}{c}D 2 \\
(\mu \mathrm{m})\end{array}$ & HVN & Rata - rata \\
\hline 1 & \multirow{3}{*}{ lasan } & 0.15 & 170 & 85 & 85 & 25.66 & \multirow{3}{*}{23.35} \\
\hline 2 & & 0.25 & 178 & 89 & 89 & 23.41 & \\
\hline 3 & & 0.35 & 188 & 94 & 94 & 20.98 & \\
\hline 4 & Batas & 0.45 & 172 & 86 & 86 & 25.07 & \\
\hline 5 & \multirow{4}{*}{ HAZ } & 0.55 & 164 & 82 & 82 & 27.57 & \multirow{4}{*}{29.38} \\
\hline 6 & & 0.65 & 160 & 80 & 80 & 28.97 & \\
\hline 7 & & 0.85 & 155 & 77.5 & 77.5 & 30.87 & \\
\hline 8 & & 1.05 & 157 & 78.5 & 78.5 & 30.09 & \\
\hline 9 & Batas & 1.25 & 148 & 74 & 74 & 33.86 & \\
\hline 10 & \multirow{3}{*}{ logam induk } & 1.45 & 148 & 74 & 74 & 33.86 & \multirow{4}{*}{33.113} \\
\hline 11 & & 1.65 & 151 & 75.5 & 75.5 & 32.52 & \\
\hline 12 & & 1.85 & 150 & 75 & 75 & 32.96 & \\
\hline & & & & & & & \\
\hline
\end{tabular}

Gambar diatas menunjukkan tabel nilai kekerasan hasil pengujian dari specimen sudut kerja pengelasan $75^{\circ}$

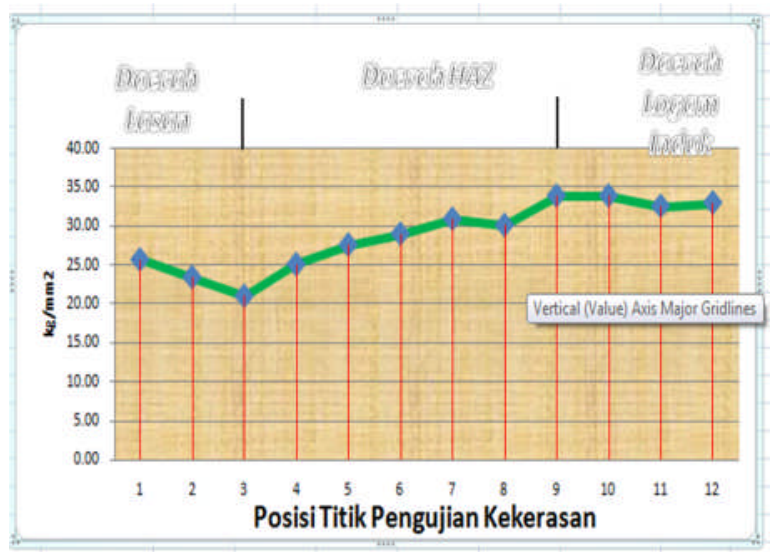

\section{Gambar 4.16 Nilai Kekerasan Hasil Las Dengan Sudut Pengelasan $75^{\circ}$}

Gambar diatas menunjukan bahwa titik 1 sampai dengan 3 adalah nilai kekerasan untuk daerah las, nilai rata - ratanya adalah $23.35 \frac{\mathrm{kg}}{\mathrm{mm}^{2}}$. Titik ke 4 yang terdapat pada grafik menunjukkan nilai kekerasan dari batas daerah lasan dengan daerah HAZ dengan nilai kekerasannya adalah $25.07 \frac{\mathrm{kg}}{\mathrm{mm}^{2}}$. Titik ke 5 sampai 8 merupakan daerah

HAZ yang memiliki nilai rata - rata kekerasan sebesar $29.38 \frac{\mathrm{kg}}{\mathrm{mm}^{2}}$. Titik 9 merupakan batas antara daerah HAZ dengan daerah logam induk yang memiliki nilai kekerasan sebesar $33.86 \frac{\mathrm{kg}}{\mathrm{mm}^{2}}$. Titik 10 sampai 12 merupakan daerah logam induk yang memiliki nilai rata - rata kekerasan sebesar 33.11 $\frac{\mathrm{kg}}{\mathrm{mm}^{2}}$. Dari data tabel dan grafik diatas nilai kekerasan tertinggi spesimen dengan variasi sudut pengelasan $75^{\circ}$ berada pada daerah Batas antara daerah HAZ dan logam induk yaitu sebesar 33.88 $\frac{\mathrm{kg}}{\mathrm{mm}^{2}}$

\section{KESIMPULAN}

Dari data yang di dapat pada saat uji mikro maka ada beberapa hal yang bisa di simpulkan dari laporan ini di antaranya :

\section{Kesimpulan}

1. Dari data yang di dapat dari penelitian bahwa dari ketiga sudut kerja pengelasan link engine hanger tipe K16 honda beat ( STKM 11A ) dengan sudut $30^{\circ}, 45^{\circ}, 75^{\circ}$ yang paling bagus untuk hasil akhir uji mikro adalah sudut $45^{\circ}$. Dimana dari 5 sample pengujian sudut kerja pengelasan $75^{\circ}$ terjadi NG pada a2 dimana actual dari a2 tidak memenuhi referensi standart welding inspection, sedangkan hasil uji mikro dari sudut kerja pengelasan $30^{\circ}$ hasil uji mikro nya masuk kategori NG dimana actual dari a1 tidak memenuhi referensi standart welding inspection dengan judgement fillet ( $\mathrm{F}$ ) di mana jenis materialnya adalah pipa STKM 11 A.

2. Untuk hasil uji kekerasan, Dari data tabel dan grafik pada penelitian uji kekerasan diatas nilai kekerasan tertinggi spesimen dengan variasi sudut pengelasan $30^{\circ}$ berada pada daerah HAZ yaitu sebesar $38.94 \frac{\mathrm{kg}}{\mathrm{mm}^{2}}$. Dari data tabel dan grafik pada penelitian uji kekerasan diatas nilai kekerasan tertinggi spesimen dengan variasi sudut pengelasan $45^{\circ}$ berada pada daerah HAZ yaitu sebesar 47.46 $\frac{\mathrm{kg}}{\mathrm{mm}^{2}}$. Dari data tabel dan grafik pada penelitian uji kekerasan diatas nilai kekerasan tertinggi spesimen dengan variasi sudut pengelasan $75^{\circ}$ berada pada daerah Batas antara daerah HAZ dan logam induk yaitu sebesar $33.88 \frac{\mathrm{kg}}{\mathrm{mm}^{2}}$.

\section{DAFTAR PUSTAKA}


1. American Welding Socity. 1996. The Everyday Pocket Hanbook For Visual Inspection and Weld discontinuities causes and remidie. United States of America ; published by American Welding Socity

2. American Welding Socity D1. 1. Structural Welding Code. United States of America ; published by American Welding Socity

3. Heather E. gilmer and Karl H. frank. 2000. Evaluation Welding of Fillet Welding Qualification Requirements. United States Departement of Trasnsportation Federal Highway Administration : Center For Transportation Research Bureau of engineering Research The University of Texas at Austin

4. Jurandir primo, PE. 2012. Welding Inspection Qualification and Testing Prosedure : PDHcenter (PDHcenter.com / PDHonline.org)

5. Sriwidharto. 1987. Petunjuk Kerja Las. Jakarta : Pradnya Paramitha

6. Standard Welding Inspection PT. Astra Honda Motor and PT. Pamindo Tiga T.

7. Sunari, 2007. Teknik Pengelasan Logam. Jakarta : Ganeca excact

8. Wiryosumarto H, Okumura T. 1991 . Teknologi Pengelasan Logam. Jakarta : Pradnya Paramitha 